\title{
慢性副鼻腔炎における上顎洞チュービング療法
}

On the treatment of inserting a drainage tube into a maxillary sinus for a patient with chronic sinusitis.

昭和大学藤が丘 耳鼻咽喉科

寉田哲 昭

key word 慢性副鼻腔炎, 保存的療法, Drainage, 上顎洞穿刺

\section{On the treatment of inserting a drainage tube into a maxillary sinus for a patient with chronic sinusitis.}

\author{
Tetsuaki Kubota \\ Dept. of otorhinolarnyngology, Showa Univ. Fujigaoka Hosp.
}

Conservative procedure of treatment for a patient with chronic sinusitis was performed by means of inserting a drainage tube into a maxillary sinus through a wall of under nasal meatus and leaving it.

It established drainage and ventilation of the maxillary sinus and insert such a medicine as Rinderon VG salve and antibiotics into maxillary sinuses. Drainage tube and instrument for inserting it were developed by us. This treatment was performed in 101 maxillary sinuses of 85 cases.

Improvement in subjective symptoms was obtained in $86 \%$ of cases, and it in X-ray finding was $73 \%$ of cases.

\section{はじめに}

上顎洞チュービング療法は下鼻道より洞内ヘドレー ンチューブを挿入留置し, 洞貯留液の持続的除去と共 に薬剤の注入を行って形態的，機能的に本来の状態に 㞍すことを意図しているものである。

この治療法は上顎洞開放手術の弊害を避け，高度な 慢性副鼻腔炎に対して一般診療所でも外来治療できる ことを目的に考案した保存的療法であるが，近年慢性 副鼻腔炎の軽症化や片側性の増加などその病態の変化 が指摘されており，現状にあった新しい治療法として 日常診療の中に導入したいと考えており，ここに報告 する。

\section{方法と成績}

1）チューブ挿入法

チューブの挿入に先立ちシュミット針による上顎洞 穿刺を行う。この時下鼻道側壁骨の厚さを知ると同時 に洗浄, 造影を行い, 貯留液の性状や洞排泄能を確認 する。

1 週間後にチューブの挿入を行うが, ボスミンで下 鼻道を開き，4\%キシロカインガーゼを挿入し十分塗 布麻酔を行う。

現在のチューブの型状は（図 2）の如くで，先端部 が約 $4 \mathrm{~mm}$ 程度の太さになっているため，まず（図 3 ）の上部に示す穿刺針で究をあける。この針は先端 が太くなっており，約 $4 \mathrm{~mm}$ の穴があくようになっ 
日本鼻科学会会誌

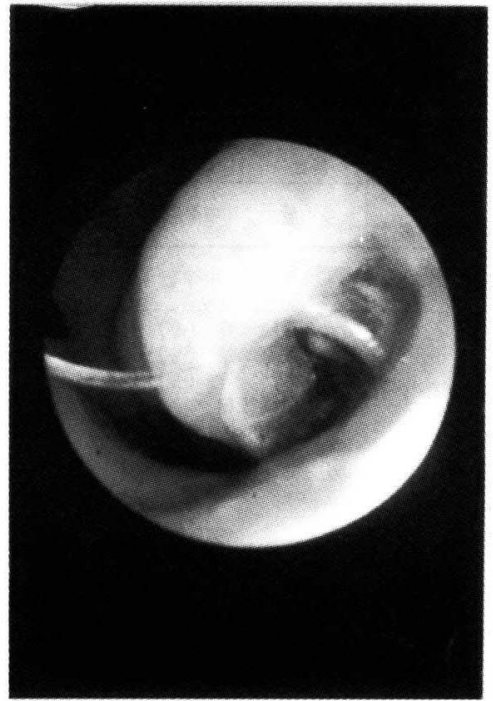

図 1 左上顎洞に留置されたチューブ

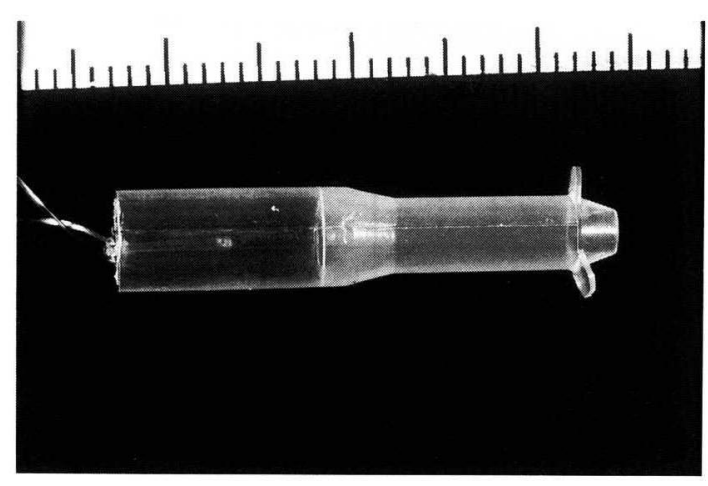

図 2 チューブの型状

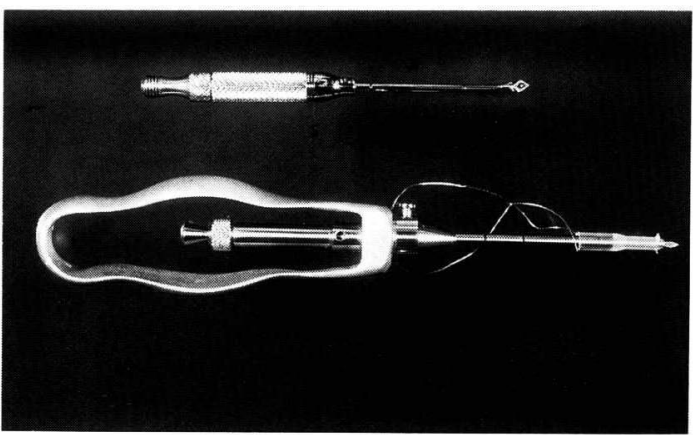

図 3 挿入器具

上. 穿刺針挿入器

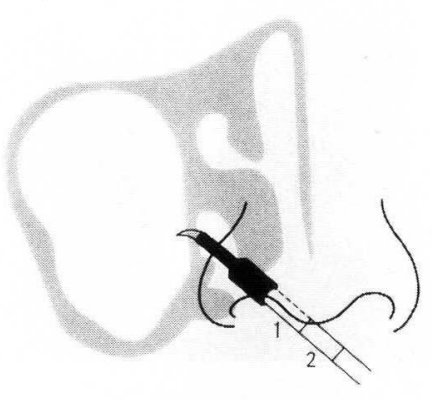

挿入方法

図4 挿入方法

ているが, シュミット針洗浄用ゴム球や注射器が接続 可能で，初加らこ針を用いシュミット針の代用と することもできる。

次に(図 4) の通り，チューブを装着した挿入器の 針先を下鼻道側壁の穿刺孔の上に当てる。この時挿入 器の横線印(1)が前鼻孔鼻橋部にくるようになってい る。次に強く挿入するとチューブの先端部が骨壁を通 るとき抵抗を感じる。

挿入は横線印(2)が鼻橋部にくるまで押し込む。これ 以上抙入すると，骨壁が薄い症例では敗れてチューブ が洞内人落下する危険がある。㨉入器のストッパーを 押すと，針先は引っ込み千ューブのみ留置されるわけ である。このようにして下鼻道に留固された子ューブ は(図 1) の如くであるが, 挿入時ボスミンでやや縮 小させた下申介は後に再び腫脹してチューブを圧して その固定を助ける。又チューブの深さは困 1 の如く下 甲介前端にそろうのが最もよく後の処置がやり易くな る。

チューブ挿入はシュミット針穿刺が可能なすべての 症例に行うことができ, チューブも自然脱落すること なく,2 - 3 年以上も長期間留置できる。しかし挿入 位置や方向が悪い場合，膿汁が固まって污染された場 合など、治療経過中に入れ換える症例はある。

2) 治療方法

チューブの挿入によって持続排膿と換気は常時行わ れるようになるが，その後の洞内処置は（図5）に示 


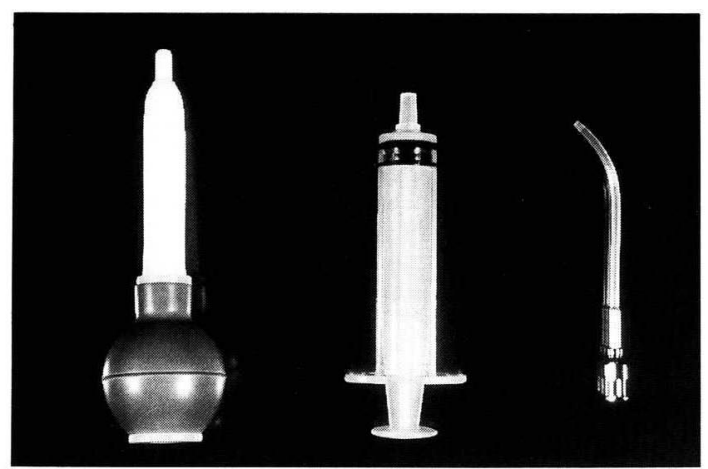

図5 薬剂注入器具

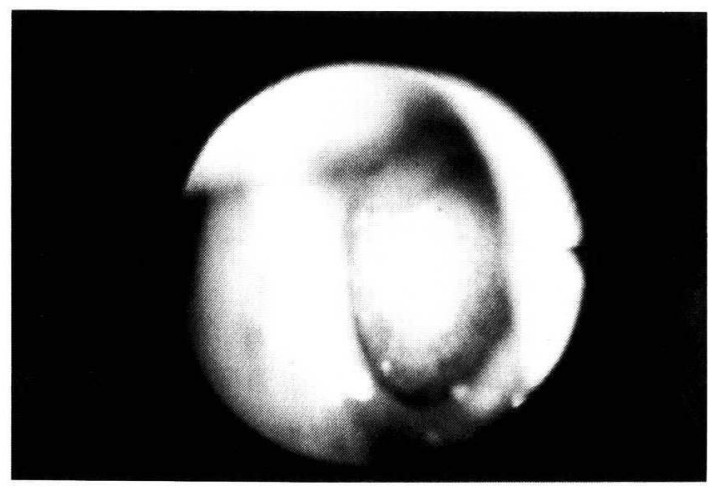

図 6 着色リノコートの排出

した彎曲したエラスターチューブを留置チューブの中 を通して行う。処置には吸引，洗浄，薬刜注入などあ るが，吸引は持続排膿でも残った少量の貯留液に対し ユニットの吸引管をエラスターチューブに当てて吸い 取り, 洗浄は $20 \mathrm{cc}$ 注射器を接続して行う。

使用薬剂は洞内よりの検出菌に感受性のある抗生剂 とリンデロン VG 軟竜が主である。リンデロン VG は主に浮腫性腫脹の病変に対して除放性ステロイド剂 として使用する。又小児で鼻汁中に好酸球のみられる 数例には，チューブより洞内へリノコートの噴霧をお こなったっこのような治療は週 1 回患者を来院させて, 自覚症状や鼻腔および洞内貯留液が消失するまで行 い,その後はチューブを留置させたまま経過観察し， レ線像の改善を待つ。

3) 対象症例

かなり以前より鼻症状が続き, 洞貯留液が証明され, 粘膜の肥厚と洞排泄障害が認められて慢性副鼻腔炎と
表 1

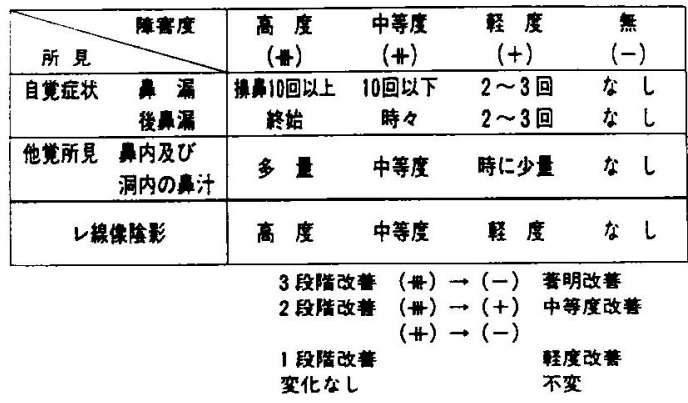

効果判定基葏

表 2 成 績

\section{5症例101側の成績}

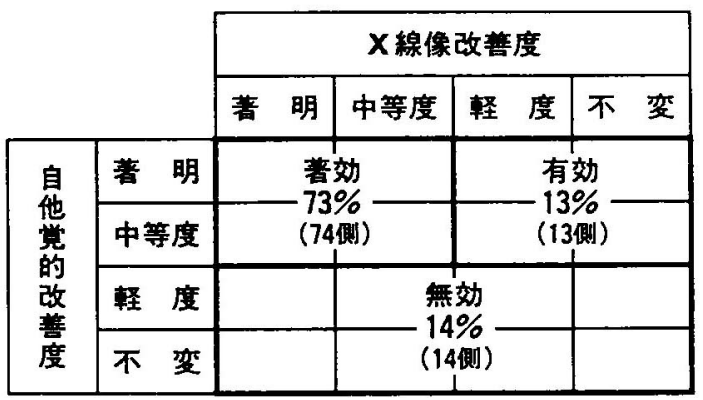

診断されたものである。

症例数は 85 例 101 側であるが，うち 10～15 歳の小 児は 17 例 31 側で全て両側性であったが, 3例では チューブ挿入は病変が高度な 1 側のみに行い, 他の症 例では両側に挿入した。

成人は 68 例 70 側で大半の 59 症例 59 側が片側性で あった。両側性は 9 例であったが，千ューブ挿入を両 側に行ったのは 2 例, 1側のみに行ったのは 7 例であっ た。

本療法は上顎洞病変の改善を目的としたもので，篩 骨洞の高度病変や中鼻道にポリーブが充満している症 例では，本法の適応外として初めから根治手術を行う か, 鼻内篩骨洞開放術を併用した鼻内管骨洞開放術を 行ったのは成人の 4 例 6 側のみである。

\section{4) 成 䋶}

判定基準は（表1）の如く行い，自覚症状，他覚的所 見，レ線所見の改善度を 4 段階に分け，著明および中 


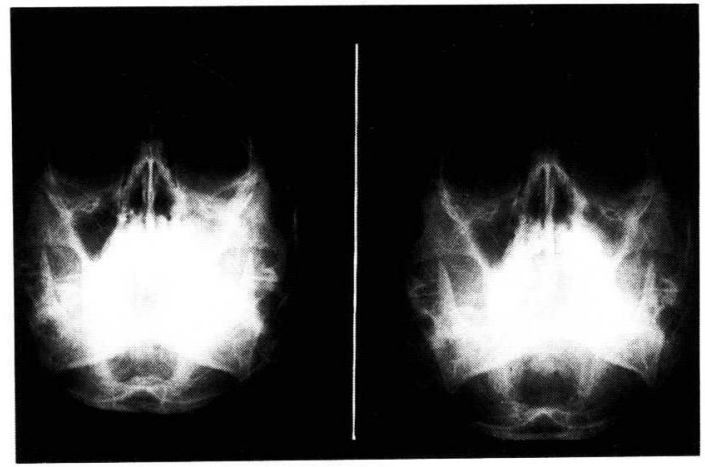

図 7 症例 1 のレ線像

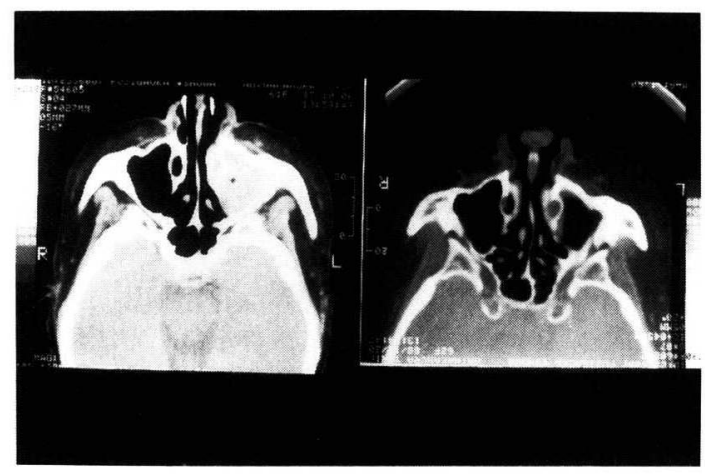

図 8 症例 1 のT 像

等度改善のみを有効とした。

自他覚的に有効でレ線像でも改善した著効例は 73 \%, 自他覚的に改善し，レ線像では改善していない有 効例 $13 \%$, 無効例は $14 \%$ であった。即ち $86 \%$ に自他 覚的改善がみられ，うち $73 \%$ にはレ線上でも改善し たわけである。無効例のうち2 例は既に根治術を行い， 他は現在も治療中である。治療期間はレ線像改善まで 6 力月より約 3 年の長期間を要した（表 2 )。

\section{5) 症例}

症例 1

57 歳 女性 左慢性副鼻腔炎

黄色膿汁が貯留し, 治療 2 年で改善した症例である。

膿汁より嫌気性菌と pseudomonas が検出され， 粘膜は著明に肥厚, 造影剂は少量しか入らず排泄障害 もあった。

チューブ挿入で約 6 力月後症状は軽快し，更に 1 年 半後レ線（図7）とCT像(図8）でも改善してきた。

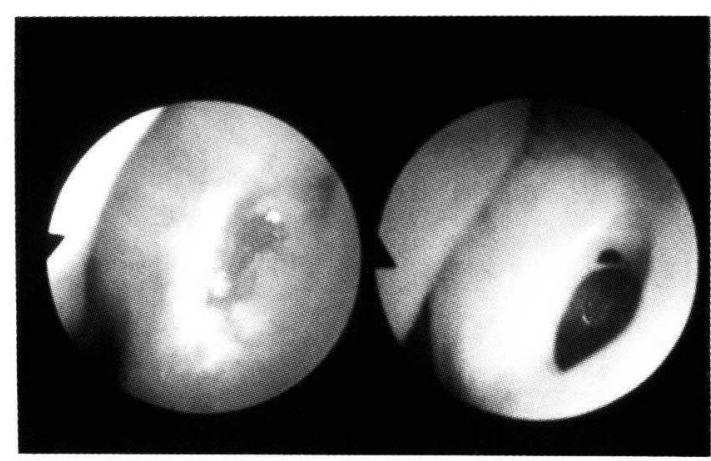

図 9 症例 1 の自然孔
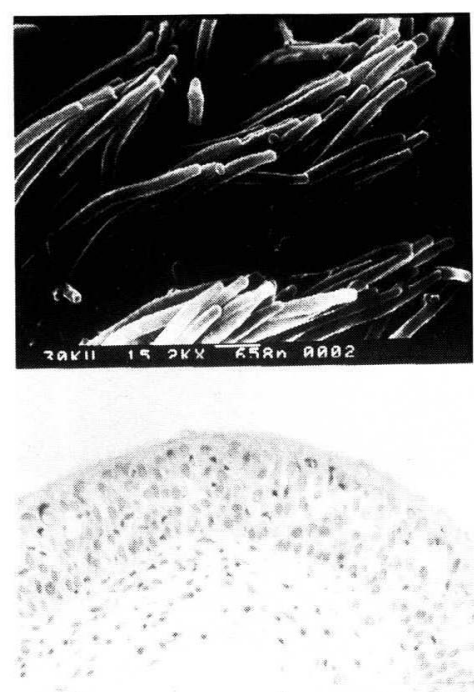

図 10 症例 1 の上顎洞粘膜（治療後）

(図9)は治療前後の自然孔で,この治療の最終目標 はこの症例の如く自然孔が開き，排泄能が正常化する ことである。

（図 10）は治療終了時チューブより鉗子を挿入し, 小組織片を採集したものであるが，約 6 力月間の薬剂 注大にもかかわらず，せん毛は障害されず，固有層の 炎症像当消失していた。

症例 2

34 歳 男性 右慢性副鼻空炎

治療 1 年 4 力月でレ線像, CT 像（四 11)にても改 善したが, 自然孔は開放せず。

そこで(困 12)の如く外来にて自然孔に電気焼灼器 


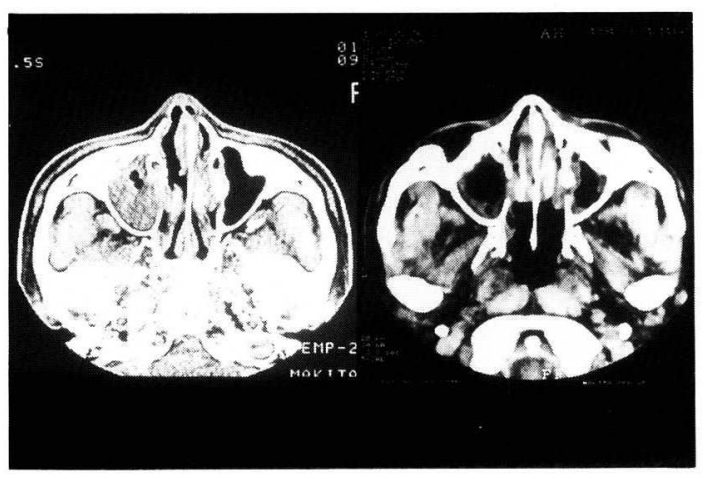

図 11 症例 2 のT 像

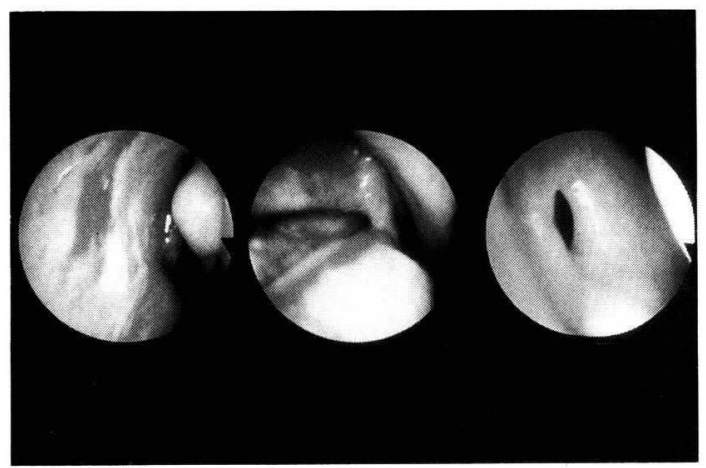

図 12 症例 2 の自然孔

左.開放しない自然孔

中. 自然孔への電極の挿入

右.開放した自然孔

の電極を挿入し，自然孔開放術を行った。

\section{考察}

従来行われてきた慢性副鼻腔炎の治療は洞粘膜の完 全除去を目的とした根治手術と酵素製郕，ネブライ ザ一を中心とした保存的療法とが大勢を占めてきた。

そして手術設備のある施設では前者に治療の主体が おかれ，煩部のう胞や煩部のしびれ感など, 術後に問 題を残す上顎洞の開放手術が必要以上に安易に行われ てきた傾向がある。

また手術設備を持なない施設では人手や医療過誤な ど社会的問題とも相まって，効果が期待うすい後者の 治療が漫然と続けられてきた。

一方慢性副鼻腔炎の病態は近年軽症化や片側性の増
怚性副竞腔炎の発症

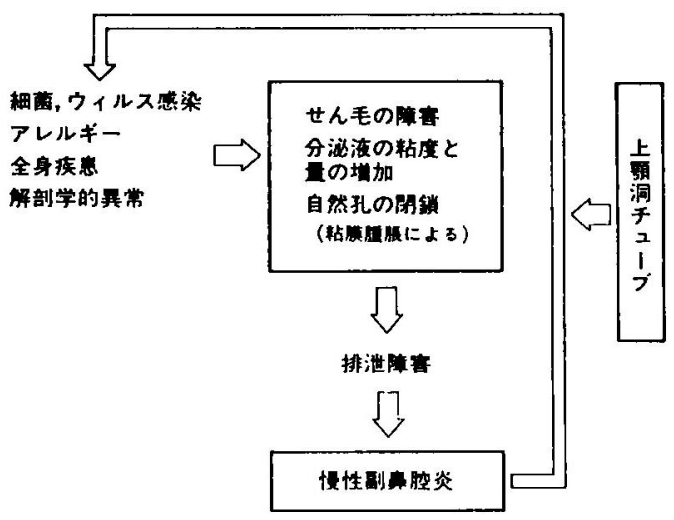

図 13 慢性副鼻腔炎の成立

加,アレルギーの関与などその変化が指摘されており， 治療法においても当然従来の画一的な方法が見直され るべきであろう。

その治療法も最近では既に変遷しつつあり, 手術療 法にお゙いても鼻内形態の修復に主体をおく方法や，鼻 内篩骨洞開放術, 下鼻道開空術, 自然孔拡大術など上 顎洞粘膜を保存した方法のみで済ませる場合や，保存 的療法でも積極的に穿刺洗浄や洞内への楽剂投与など を反復する方法が以前より盛んになりつつある。

この上うな現況の中で上顎洞開放手術の弊害を避 け，高度な慢性副鼻腔炎でも一般診療所で外来治療で さる, 効果的な保存的方法として上顎洞チュービング 療法を考案し，実施してきた。

慢性副鼻腔炎の成立機転は（四 13）の如く既に広く 認められている。本法の意図しているものは分泌液の 粘度と量の増加，自然孔の閉鎖が排泄障害の主因であ ると考え，排泄障害が招く悪循環を断ち切るため, チューブを挿入し，さらに薬剤を注入して積極的に消 炎をはかることによって，粘膜の浮腫性腫脹を軽減 し，最終的に自然孔を開大させることにある。又せ ん毛障害の有無に関しては, 我々が慢性副鼻腔炎粘膜 のせん毛機能を電気光学的及び病理組織学的に検索 し，部分的にはあっても広範囲に障害されている症例 は少ないという結論にもとづいている。

チューブ摴入によって貯留液の催炎物は持続的に排 出されるが, 上顎洞底部に少量残留したものや, 貯留 が激しいものに対しては更に洗浄を行う。 
薬剤は細菌が認められた症例には当然感受性ある抗 生剂を注入するが，その $80 \%$ 以上に細菌が検出され， 慢性副鼻腔炎であっても細菌対策が重要であることが 判る。粘膜の浮腫性腫脹には主にリンデロンVGを, 好酸球が鼻汁中陽性なものにはリノコートを使用して みたが，薬凨の郕型は留置チューブより流出しやすい 液状ではなく, 粘膜の粘液せん毛輸送機能によって洞 内一広がり, 自然孔, 中鼻道へと至ってその間, 長時 間の薬剤効果が期待できる除放性のものがよいものと 考えている。リンデロンVGでは数日間，又リノコー トでは $2 \sim 3$ 時間洞内に残留しているのが確認されて いる。

一方このように様々な薬剤を注入し，粘膜の機能を 損わないか心配もある。本法は粘膜の機能保存する観 点より試験切除による組織変化の検索には無理がある が, 1 2 の少数例での結果は(図 10) に示す如くで, せん毛障害もなく, 粘膜固有層においても炎症の消退 がみられる。

本法の最も明らかな効果は自他覚的な改善のみでな く，レ線像での明らかな改善である。更に CT 像でみ られる如く高度な粘膜の腫脹も消失し, 従来非可逆性 と思われていた炎症粘膜の腫脹も大半は可逆性である ことが証明された。今回効果判定はレ線像の改善度ま での判定で行ったが, 最終的には粘膜腫脹の消退後に 自然孔が開放することである。しかし自然孔は内視鏡 下観察では閉鎖したままの症例もかなりの数にのぼ ク，チューブ抜去後炎症再燃の可能性がある。このよ うな症例に対し，さらに長期間チューブを留置させた ままとしているが著者は外来で簡便にできる立場より 電気焼灼器の電極を自然孔に捚入焼灼し, 自然孔開放 術なるものを現在試みつつあるが (図 12), その結果 は今後に待ちたい。

今回の成績は 85 症例 101 側で自他覚的に改善し, レ線像でも改善した著効例 73\%, 自他覚的に改善した が，レ線像では改善していない有効例 13\%, 無効例は 14\%で良好な結果と思われた。

このうち小児副鼻腔炎に属する 10１5 歳に限る と 17 症例 31 側で著効 $61 \%$, 有効 10\%, 無効例 $29 \%$ で $71 \%$ に効果がみられたが，小児だけに限定した成績 は成人の場合より下回るものであった。

小児では両側性で粘膿性鼻汁の症例が多く, アレル ギーなどの内因性要因をもった高度病変症例も多く含 まれていたためであろう。それに反し成人では大多数
が片側性で細菌が検出された黄色膿汁の症例が多かっ たがこれらも，近年における病態の変化の一つと考え られ本法のような治療法が一層意味あるものになると 思われた。

本法と類似な治療法としては保存的立場では頻回の 副鼻腔洗浄療法が, また手術的立場からは下鼻道開空 術が以前より行われている。

副鼻腔洗浄療法の成績について荒木は小児を对象と して $40 \%$ 前後と報告しており，間島は 1 段階以上の 改善が $74 \%$ と述べている。改善率については症例の 病態, 効果判定の方法, 洗浄回数, 薬剂使用の有無な どにより一概に論ずることはできないが, 著者の チュービング療法は上顎洞の高度な病変の症例が X 線 上でも明らかに $61 \%$ と改善しており恐らく洗浄療法 の成績を上回るものと思われる。洗浄療法と比較して 本法の特徵は持続排膿と除放性薬剤としてステロイド 軟高を使用することにあるが, 一方洗浄療法では水流 圧によって閉鎖自然孔を開放する可能性もあり，今後 確認したい点である。

下鼻道開空術はV an Alyea の発表以来多くの報告 がある。Tankkanen らは若年者の開空術で 78\%の 効果を報告している。しかし最近では Harlan R ら は小児の開空術の成績が術後 1 力月で $40 \%, 6$ 力月で $27 \%$ と報告し，有効な方法ではないと述べている。 その理由として開空部が閉鎖しやすいこと, 篩骨洞の 病変や中鼻道骨形態の異常には对処できないことなど を挙げており，同じように下鼻道開空術が有効でない とする報告も多い。下鼻道開空術は著者の経験でも 1 2 カ月の短期間で開空部が肉芽性に閉鎖を来たす 場合が多かった。病的粘膜が回復するにはかなりの長 い期間を要し，チュービング療法でも時に小児では $2 \sim 3$ 年が必要であったが，その間薬剤注入など局所 療法を行わねばならず，たと之狭くても長期にわたり 交通路があるチューブの方がよいのではないかと考え ている。

またチュービング療法の目標は上顎洞であり，上顎 洞が改善すれば中鼻道や篩骨洞の病変が 2 次的に改善 する場合もあるが, 篩骨洞の高度な病変や中鼻道の著 明なポリープがみられる場合は排泄能が改善される可 能性は少なく, 初めから本法の適応外として除外して いることも本法の成績を良好にしている理由と考えら れる。ただ本法は非常に長期間を要すること, 節骨洞, 中鼻道病変が少ないことなど選択条件もあり, 適応症 
例を吟味すると同時に患者の本法への理解と治療意欲 を得るように考虑して行うべきものと思われる。

\section{文献}

1) 寉田哲昭 : 特集 副鼻腔炎の保存的治療の検討 とその限界「上顎洞チュービング療法」耳喉 59 : $283 \sim 288,1987$.

2）窪田哲昭：慢性副鼻腔炎の最近の治療から。日本 医事新報 $3377: 29 \sim 34,1989$.

3) 窪田哲昭 : 副鼻腔炎の局所療法。日本鼻科学会学 会誌 $28: 246 \sim 249,1989$.

4) 窪田哲昭：特集 小児副鼻腔炎の治療一特にチュー ビング療法を中心として一。耳喉 $62: 641 \sim 646$

5) 吉田篤正, 窪田哲昭 : 上顎洞排泄能と線毛運動。 日本鼻科学会会誌 $22: 279,1983$.

6) 吉田篤正：慢性副鼻腔炎における粘膜線毛運動と その病理所見。日本鼻科学会会誌 $23: 215 \sim 216$,
1984

7）荒木昭夫 : 特集 副鼻腔炎の保存的治療の検討と その限界「小児副鼻腔炎の追跡調查」耳喉 59 : $261 \sim 266,1987$.

8) 間島雄一：副鼻腔炎の局所療法「上顎洞洗浄, 注 入療法」。日本鼻科学会会誌 $28: 243 \sim 245,1989$.

9) Van Alyea, O. E.: Management of Chronic Sinus Disease. Ann Otol Rhinol Laryngol, $54: 443 \sim 457,1945$.

10) Tankkanen, J., et al. : Adenotomy, Antrostomy and Caldwell-Luc Operation in the Treatment of Chronic Bronchitis in Children. Acta Otolaryngol $74: 371 \sim 374,1972$.

11) Hardlan R., et al. : Nasal Antral windows in Children : A Retrospective Study. Laryngoscope $100: 643 \sim 646,1990$. 